\title{
Assessing the effectiveness and efficiency of the provincial MuniMEC forum inter-government relations structures in the Eastern Cape Province, South Africa
}

\begin{tabular}{|c|c|}
\hline \multicolumn{2}{|c|}{$\begin{array}{l}\text { Authors: } \\
\text { Zolani Tafeni }{ }^{1,2} \text { (D) } \\
\text { Bheki Mngomezulu }\end{array}$} \\
\hline \multicolumn{2}{|c|}{$\begin{array}{l}\text { Affiliations: } \\
\text { }{ }^{1} \text { Department of Public } \\
\text { Management and Economics, } \\
\text { Faculty of Management } \\
\text { Sciences, Durban University } \\
\text { of Technology, Durban, } \\
\text { South Africa }\end{array}$} \\
\hline \multicolumn{2}{|c|}{$\begin{array}{l}{ }^{2} \text { Department of Finance, } \\
\text { Department of Employment } \\
\text { and Labour, East London, } \\
\text { South Africa }\end{array}$} \\
\hline \multicolumn{2}{|c|}{$\begin{array}{l}{ }^{3} \text { Department of Political } \\
\text { Science, Manaagement } \\
\text { Sciences, University of the } \\
\text { Western Cape, Cape Town, } \\
\text { South Africa }\end{array}$} \\
\hline \multicolumn{2}{|c|}{$\begin{array}{l}\text { Corresponding author: } \\
\text { Zolani Tafeni, } \\
\text { zolani.tafeni@gmail.com }\end{array}$} \\
\hline \multicolumn{2}{|c|}{$\begin{array}{l}\text { Dates: } \\
\text { Received: } 01 \text { Sept. } 2021 \\
\text { Accepted: } 11 \text { Nov. } 2021 \\
\text { Published: } 31 \text { Jan. } 2022\end{array}$} \\
\hline \multicolumn{2}{|c|}{$\begin{array}{l}\text { How to cite this article: } \\
\text { Tafeni, Z. \& Mngomezulu, B., } \\
2022 \text {, 'Assessing the } \\
\text { effectiveness and efficiency } \\
\text { of the provincial MuniMEC } \\
\text { forum inter-government } \\
\text { relations structures in the } \\
\text { Eastern Cape Province, South } \\
\text { Africa', Journal of Local } \\
\text { Government Research and } \\
\text { Innovation } 3(0), \text { a42. } \\
\text { https://doi.org/10.4102/ } \\
\text { jolgri.v3i0.42 }\end{array}$} \\
\hline \multicolumn{2}{|c|}{$\begin{array}{l}\text { Copyright: } \\
\text { (C) 2022. The Authors. } \\
\text { Licensee: AOSIS. This work } \\
\text { is licensed under the } \\
\text { Creative Commons } \\
\text { Attribution License. }\end{array}$} \\
\hline \multicolumn{2}{|l|}{ Read online: } \\
\hline $\begin{array}{l}\text { 口pta } \\
\text { artar }\end{array}$ & $\begin{array}{l}\text { Scan this QR } \\
\text { code with your } \\
\text { smart phone or } \\
\text { mobile device } \\
\text { to read online. }\end{array}$ \\
\hline
\end{tabular}

Background: This research examines the effectiveness and efficiency of the Provincial MuniMEC in facilitating the Inter-Government Relations (IGR) arrangements for improvement provincial service provision mandate in the Eastern Cape Province. Post-1994 local government reforms led to the establishment of wall-to-wall municipalities to accelerate municipal services provision and the introduction of systemic municipal service provision guidelines as part of socio-economic transformation.

Objective: The effectiveness and efficiency of this plan remains unclear. This research intends to address this issue with the view to contribute on strategies that can be adopted to improve service provision through the integration of IGR structures.

Method: The study adopted a qualitative approach by administering structured questionnaires to purposely selected participants and carefully reviewed various documents and policies in IGR and Local Government. The questionnaire analysis included theoretical propositions that incorporated the efficiency of the provincial MuniMEC IGR structures, the legal IGR framework, and the participatory approach in MuniMEC IGR structures by stakeholders.

Result: One core finding is that the MuniMEC IGR structure has contributed to the coordination and integration of government service delivery interventions at municipalities, yet little empirical evidence explains this improvement. Research shows that government's IGR obligation to coordinate the integration of government service delivery interventions to municipalities could have more impact on service delivery improvement than the utilisation of a single-oriented approach. This study provides lessons on that any regulation without a structured implementation plan leads to poor service delivery. A key recommendation is that both the national and provincial government need to promote shared service delivery through the enhancement of the IGR framework.

Keywords: intergovernmental relations; socio-economic development; service delivery; municipal private partnerships; effectiveness; efficiency.

\section{Introduction}

This study aimed to determine the effectiveness and efficiency of the Eastern Cape provincial Municipalities and Members of the Executive Committee (MuniMEC) IGR structure in addressing service delivery challenges at municipal level. The Eastern Cape province is characterised by a total of 45 municipalities, which are comprised of six districts, two large cities and 37 local municipalities. Section 40(1) of the Constitution of the Republic of South Africa (Act 108 of 1996) states that government is established as national, provincial, and local government spheres which are distinctive, interdependent, and interrelated in nature. The element 'distinctive' basically refers to the autonomy enjoyed by the spheres, implying the degree to which each sphere is the final decision-maker on a particular matter that falls within its jurisdiction. Through this constitutional exercise, a decentralised governance system among the three inter-related spheres emerged, leading to the development of a systematic intergovernmental relations (IGR) system which gave effect to the cooperative government principles (Mdliva 2012:14). To give effect to these principles, on 15 August 2005, the IGR Framezork Act was promulgated. The Act provides for:

$[A] n$ institutional framework for the three spheres of government to facilitate coherent government, effective provision of services, to monitor the implementation of policy and legislation, and the realisation of developmental goals of government as a whole. (www.dlpg.org.za)

The study parameters basically focused on the MuniMEC IGR structure because it came into effect in terms of the IGR Act (Act 13 of 2005). 
The aim of the IGR Framework Act 13 of 2005, was 'to assess the effectiveness of the IGR framework in promoting and facilitating settlement of intergovernmental disputes, and service delivery in South Africa (SA)'.

\section{Historical background}

Before the dawn of a democratic South Africa in 1994, uneven administration was systematically designed to provide and deliver services to communities along racial lines. This implied that only a certain ethnic group could benefit from the social and economic services which the then government provided. The idea of IGR was poorly and inadequately defined, which made it impossible for shared socio-economic development (Mdliva 2012). All the power was in the central government despite the division of central, regional, and local levels of government (Levy \& Tapscott 2001:4). However, towards the end of the apartheid rule, IGR was characterised by autocratic central rule, which led to increased administrative inefficiency, corruption, and minimal popular legitimacy. The deficiency by the provincial legislatures to significant law-making function came as a serious hindrance to democratic servicing of all citizens regardless of their racial identity. The only function that the then provincial legislatures had was to endorse legislation from the central executive, which showed a level of dependency and a closed system. At the same time, no real powers were given to local authorities. The local government was only regarded as a government service provider rather than an independent level of government.

The White Paper on Local Government (1998:15) listed some of these challenges as follows: 'skewed settlements', 'extreme concentration of taxable economic resources in former white areas', 'huge backlogs in service infrastructure in historically underdeveloped areas', 'creating viable municipal institutions for dense rural settlements', 'inability to leverage private sector resources for development', 'entrenched modes of decision-making, administration and delivery', 'the need to rebuild relations between municipalities', as well as 'substantial variations in capacity and the local communities they serve'.

The IGR framework is still new in the South African context, as the nine provinces were only formed after 1994 and the local government system was only introduced in 2000. This alone has contributed to the ongoing intense debate on whether the basic structures laid down in the Constitution are the right ones or whether restrictions are needed to affect the most needed structured system of government. This has diverted attention from the urgent question of how these structures can function efficiently and effectively (National Development Plan 2012:432). While we acknowledge the fact that the system of governance is the result of compromise, this is not unique to South Africa, but is the case all over the world. In the real world of governance, there is no country that can set up its governmental framework in isolation from the politics of the day.
South Africa's approach of decentralisation in implementation responsibilities while retaining national oversight and using central finding mechanisms to achieve joint redistribution of services is no different from what is the case in other countries.

The challenge is to ensure that these structures benefit all sorts of people. The Constitution sets out the division of powers and functions between national, provincial, and local government. But no written document can set out all the features of the intergovernmental system. The Constitution provides a set of principles on how the system should work, but does not give instructions on how to translate these principles into action. These include the principles of subsidiarity and differentiation, which allow a great deal of flexibility in the application of the Constitution. It takes time and experience to find the best way to implement these principles (Molebeleli 2018:89).

The experiences of many countries suggest that building effective and efficient relations between the different government spheres requires a considerable amount of time, effort and will (Stats SA 2019:185). Currently, the arrangement of the three government spheres provides basis on which to build. At the same time, it highlights a need to focus on the key issues that require rapid, shared and sustainable attention for effective IGR.

According to RSA (Act 108 of 1998) and RSA (1998:39), national and provincial governments are mandated to strategically coordinate and facilitate IGR throughout the government system in order to provide the most needed public services to the communities. Apart from the three spheres of government responsibility, the organs of the state are equally bound by the cooperative governance principles in strengthening IGR functionality. Consequently, the interdependence and relative autonomous status under the Constitution of these spheres of government presents significant strengths to South Africa. It also means that there are limits to the extent to which the spheres can direct or control the approaches taken by each other.

Reddy (2001:22) writes that 'various uncertainties regarding the responsibilities and administrative allocation between the different spheres of government still exist'. The extent to which these uncertainties will affect the capacity to provide services needs to be given special consideration.

The primary objectives of the IGR are meant to improve and coordinate structured service delivery intervention at a municipal level towards sustainable and shared socio-economic growth. In this regard, the study sought to evaluate and determine the effectiveness and efficiency of the MuniMEC IGR structure in service delivery through a case study approach.

\section{Problem statement}

Despite the introduction of the Provincial IGR framework and its implementation strategies since the evolution of the local government, the South African municipalities are still 
characterised by a series of poor delivery of basic municipal and socio-economic services to their citizens (Masiya et al. 2019:20). The Eastern Cape Provincial Government leadership led by the Premier, Mr Pumulo Masaulle in his State of the Province Address (2017) committed to improve government service delivery by the interventions through IGR. Although the is a need for the strengthening of IGR structures in the province, there are still gaps in enhancing political leadership, accountability and collaboration towards rapid service provision and delivery (Tafeni \& Mngomezulu 2020:600). Consequently, the MuniMEC IGR structure, which is a combination of Mayors (district and local municipalities) and MEC for Cooperative Governance \& Traditional Affairs (CoGTA), came into existence as a shared approach in dealing with service delivery unrests in the province. Uncertainty abounded around the potential success of this IGR structure because of an already existing number of structures with similar intent.

In South Africa there has been frequent mistrust and conflict between the different spheres of governments. This has undermined the efforts to overcome obstacles in the path of their success. The cost of such chronic uncertainty is enormous. This has led to a situation in which decisions are not being made as a wait-and-see attitude prevails. For example, the protracted debate over the transfer of responsibility for electricity distribution from municipalities to regional electricity suppliers resulted in municipalities underinvesting in the maintenance and upgrading of electricity distribution infrastructure (National Development Plan 2030).

The primary objective of the study was to evaluate and determine the effectiveness and efficiency of the MuniMEC IGR structure in addressing service delivery shortcomings. The intention is to highlight best-practice endeavours which in turn would inform a suitable conceptual approach on which future IGR structures could be modelled.

\section{Literature review}

\section{Overview of inter-government relations role in service delivery}

The slow delivery and provision of public services by government and municipalities to a larger extent, is a result of inadequate coordination and structured development, aimed at enhancing local economic and rural development. The dissatisfaction and the frustrations with regard to poor service delivery has, on several occasions, led to service delivery protests by the communities (reference). This is against the background that government promotes structured IGR to radically improve socio-economic conditions in the province and enhance delivery of services to the people. The hope is that this development-oriented IGR structure model will ultimately improve services, while avoiding unemployment, poverty and inequality (Eastern Cape Planning Commission in their diagnostic report of 2013). According to Lemon, O'Meara and Winchester (2004:67), South Africa was once rated with the best developed infrastructure. However, the indicators currently depict a different picture with issues which have emerged since the 2009 political landscape. This resulted in immense infrastructure backlogs because of poor infrastructure maintenance and management. The past regime's governance approach also contributed to the currently skewed socioeconomic development as a result of centralised governance (ECSECC 2015:23).

The Presidential Review Committee (PRC) (1998) noted that:

$[T]$ he relationship between and within different spheres of government had, at that time, emerged as a key concern and weaknesses were reported in the structure and practices of intergovernmental relations. (ch 2, para 2.4)

Despite the existence of the IGR legislative framework, there is still uncertainty among governments over the exact responsibilities and functions of the different government administrative levels with specific reference to responsibilities of concurrency, thus presenting the Eastern Cape Province with a negative outlook for socio-economic development. Poor coordination within and between different government spheres, departments and municipalities contributes to incapacity to implement government programmes and subsequently hinders municipal basic service delivery.

However, despite all these problems, South Africa has several reputable development finance agencies that strengthen the government's service delivery arm. These include statutory bodies such as the Finance and Revenue Commission, the Auditor-General, the State Tender Board, the Public Protector, the President's Co-ordinating Council, Interdepartmental Forums, the South African Local Government Association, the Ministerial Forums of the National Council of Provinces, Ministers and members of the Executive Council and other agencies that can contribute to better service delivery.

South Africa's Cabinet Lekgotla endorsed the introduction of a new outcomes-based approach to prepare development plans and to help in service delivery improvement. This outcome-based approach involved a series of strategies and activities that contributed directly to the achievement of the outcome. The outcomes approach came as a government's performance measure of programmes impact at community level in improving the general welfare of citizens. Furthermore, the former President of the RSA, in his State of Nation Address (2010), announced the outputs for each of these outcomes for the period 2010-2014. He stated that a high level 'performance agreement' and a fully detailed and negotiated 'delivery agreement' was expected to be developed by the Minister and the Department with key partners who needed to co-operate to deliver these outputs (Mdliva 2012:8; Presidency, Statement 2010:5).

Notwithstanding the efforts, limited and capacity constraints for IGR between government departments has created a service delivery gap. MuniMEC IGR initiatives have emerged over the past 5 years to provide political and administrative support to government's service delivery coordination 
interventions. This is largely because of internal pressure arising from increasing levels of unemployment, competing demands for dwindling national resources, escalating crime and the deteriorating state of existing infrastructure. This has compelled many governments to introduce Provincial IGR arrangements (Budget Speech 2014).

\section{Research methodology}

According to Bryman (2016:5), the term 'social research' refers to research on topics that relate to issues relevant to social scientific fields such as sociology, human geography, social policy, politics, and criminology. Babbie (2015:89) opines that all scientific social research has a research design that identifies the key research factors, data collection technique and data analysis approach and how they interact to ensure that the final findings of the research report meet the original research questions. The research design of this study is a roadmap for conducting scientific research and links the empirical data collection to the original research questions and finally to the conclusions. This study used a cross-sectional survey design.

On the other hand, methodology is broader than research methods and yet very critical in that it provides theoretical groundwork for the research method. Dunne et al. (2012:162) defines methodology as 'the study of, or a theory of, the way that research methods are used in undertaking a scientific study'. Eventually, it comprises the descriptive analysis of research methods and highlights the resources and limitations thereof. Methodology sets the philosophical basis for the research. In social research there are two methods that are predominantly used in conducting any scientific research, namely, quantitative research method and qualitative research method. For the purpose of the research problem and questions a quantitative research approach was used in this study. In quantitative research, the word 'quantity' implies that this research involves a study by gathering quantifiable data (Bryman 2004:76) cf. Mditshwa (2012:23). Quantitative methods are used when the purpose of the research is to arrive at universal statement and when the research seeks to assign figures to observations (Antwi \& Hamzak 2015:221).

The researcher administered structured questionnaires for data collection. According to Lucey (2002), a questionnaire:

[S]hould realise the following objectives: It should reflect accurate information regarding the research study; it should meet the aims of the research; and it should be implemented within the ambit of available time and resources. (p. 85)

The researcher designed structured questionnaires and sent them personally via email to 47 respondents who were purposefully selected because they were directly involved in the MuniMEC IGR structure operations.

The questionnaires were administered to the Members of the Executive Councils, Executive Mayors and Mayors, Head of Departments and Municipal Managers from OR Tambo
District Municipality in the Eastern Cape Province. Out of the 47 questionnaires administered, 34 (72\%) were received back as reflected in Table 1 and the data were analysed using Statistical Package of Social Science (SPSS). The questionnaire was designed in such a way that it triggered practical reflections by the respondents covering the aspects of the MuniMEC IGR performance shown in the figure below in line with the research objectives. The questionnaire including the covering letter was in English language to improve the response rate.

\section{Results and discussion}

As stated earlier, the aim of the study was to evaluate the effectiveness and efficiency of the MuniMEC IGR structure in coordinating government (national and provincial) service delivery intervention at a local government level. Both national and provincial governments have an immense role to play in the local government sphere with regard to IGR (Republic of South Africa 1998:39-40). Section 40(1) of the Constitution (Act 108 of 1996) of the Republic of South Africa stipulates three spheres of government, namely, national, provincial, and local spheres, which are interdependent, distinctive, and interrelated in nature.

Table 2 presents the results on Provincial MuniMEC forum efficiency. In the Table 2 participants were requested to rate the efficiency of MuniMEC. Only a total of 37.06\% (24.12\% often $+12.94 \%$ always) respondents considered Provincial MuniMEC IGR as efficient in co-ordinating provincial strategic partners towards the provision of services in a rapid, shared, and sustainable manner. In terms of the Provincial IGR Strategy (2016), the MuniMEC structure aimed at improving efficiency by maintaining solidarity among the politicians and administrators. On the one hand, a total of $25.8 \%$ of respondents did not regard the MuniMEC structure efficient in solving the challenges faced by provincial governments and on the other hand, $37 \%$ of respondents were uncertain about the efficiency of the MuniMEC IGR structure. When considering the objectives of MuniMEC, this gives a negative impression about the MuniMEC IGR structure.

TABLE 1: Questionnaire distribution.

\begin{tabular}{lccc}
\hline Category & \multicolumn{3}{c}{ Questionnaires } \\
\cline { 2 - 4 } & Total distributed & Total number returned & $\mathbf{\%}$ \\
\hline MEC's & 3 & 3 & 100 \\
Mayors & 20 & 15 & 75 \\
HODs/CEOs & 4 & 3 & 75 \\
Municipal Managers & 20 & 13 & 65 \\
\hline Total & $\mathbf{4 7}$ & $\mathbf{3 4}$ & $\mathbf{7 2}$ \\
\hline
\end{tabular}

MEC, Member of the Executive Committee; HOD, Head of Department; CEO, Chief Executive Officer.

TABLE 2: Provincial MuniMEC forum efficiency.

\begin{tabular}{lcccccc}
\hline Frequency & B1 & B2 & B3 & B4 & B5 & Total average \\
\hline Never (1) & 5.8 & 5.8 & 5.9 & 5.9 & 20.6 & 8.8 \\
Rarely (2) & 14.7 & 8.8 & 11.8 & 23.5 & 26.5 & 17.0 \\
Sometimes (3) & 35.3 & 52.9 & 26.5 & 38.2 & 32.3 & 37.0 \\
Often (4) & 26.5 & 23.5 & 35.3 & 20.6 & 14.7 & 24.12 \\
Always (5) & 17.6 & 8.8 & 20.6 & 11.8 & 5.8 & 12.9 \\
\hline Total\% & $\mathbf{1 0 0}$ & $\mathbf{1 0 0}$ & $\mathbf{1 0 0}$ & $\mathbf{1 0 0}$ & $\mathbf{1 0 0}$ & $\mathbf{1 0 0}$ \\
\hline
\end{tabular}


This relates to aspects such as the reflection of municipal needs on the MuniMEC agenda, level of commitment to the implementation of resolutions taken and bridging of gap between the three spheres of government in terms of strategic coordination and integration of service delivery interventions.

Table 3 presents the findings on provincial MuniMEC. In terms of the provincial MuniMEC functionality, $38.8 \%$ of the respondents considered that the MuniMEC IGR structure is not functional with regard to its ability to resolve service delivery backlogs and that it does not have the capacity to resolve IGR challenges and other governance, social and economic challenges facing government at municipal level. A total of $46.5 \%$ of respondents considered the MuniMEC as functional in implementing the above-mentioned aspects, while $14.7 \%$ of respondents were not sure about its functionality or non-functionality. The White Paper on Local Government of 1998 (Republic of South Africa 1998) affirms that 'all spheres of government are obliged to observe the principles of co-operative government put forward in the constitution'.

Table 4 presents the MuniMEC IGR structure legal framework. A total of $68 \%$ respondents strongly suggested that South Africa had a credible IGR policy framework for coordination and integration of government service delivery interventions at municipal level. This further revealed a $16 \%$ of respondents who did not agree with the credibility of the IGR policy framework in South Africa, while $15.7 \%$ of respondents remained neutral. Given the above, this implies that for the local government to enhance service delivery it should take necessary measures to strengthen the MuniMEC IGR structure to fast-track the social and local economic development of the municipalities.

In terms of participation of the MuniMEC members [sector departments, and municipalities in this case], $46.06 \%$ of respondents agreed that they participated in the development agenda and programme setting of the MuniMEC structural arrangements. $25.45 \%$ of the respondents on the other hand

\begin{tabular}{lcccccc}
\multicolumn{7}{l}{ TABLE 3: Provincial MuniMEC functionality. } \\
\hline Part A & C1 & C2 & C3 & C4 & C5 & Total average \\
\hline Strongly disagree (1) & 8.8 & 23.5 & 23.5 & 2.9 & 2.9 & 12.3 \\
Disagree (2) & 50.0 & 44.1 & 44.1 & 26.5 & 5.9 & 34.1 \\
Neutral (3) & 26.5 & 17.6 & 8.8 & 14.7 & 5.9 & 14.7 \\
Agree (4) & 8.8 & 11.8 & 11.8 & 32.4 & 47.1 & 22.3 \\
Strongly agree (5) & 5.9 & 2.9 & 11.8 & 23.5 & 38.2 & 16.5 \\
\hline Total\% & $\mathbf{1 0 0}$ & $\mathbf{1 0 0}$ & $\mathbf{1 0 0}$ & $\mathbf{1 0 0}$ & $\mathbf{1 0 0}$ & $\mathbf{1 0 0}$ \\
\hline
\end{tabular}

TABLE 4: The MuniMEC inter-government relations structure legal framework.

\begin{tabular}{lccccccc}
\hline Frequency & D1 & D2 & D3 & D4 & D5 & D6 & Total average \\
\hline Strongly disagree (1) & 2.9 & 5.9 & 0.0 & 2.9 & 2.9 & 8.8 & 3.9 \\
Disagree (2) & 8.8 & 23.5 & 0.0 & 8.8 & 8.8 & 23.5 & 12.2 \\
Neutral (3) & 11.8 & 11.8 & 14.7 & 17.6 & 11.8 & 26.5 & 15.7 \\
Agree (4) & 41.2 & 32.4 & 47.1 & 47.1 & 38.2 & 32.3 & 39.7 \\
Strongly agree (5) & 35.3 & 26.5 & 38.2 & 23.5 & 38.2 & 8.8 & 28.4 \\
\hline Total\% & $\mathbf{1 0 0}$ & $\mathbf{1 0 0}$ & $\mathbf{1 0 0}$ & $\mathbf{1 0 0}$ & $\mathbf{1 0 0}$ & $\mathbf{1 0 0}$ & $\mathbf{1 0 0}$ \\
\hline
\end{tabular}

disagreed with this question, suggesting that MuniMEC IGR structure agenda and programme setting never considered their institution's inputs, while $27.45 \%$ of respondents were undecided (see Table 5). The local government MuniMEC IGR structure cannot fully grasp the exact needs of municipal needs by merely conducting a desktop exercise, but by ensuring that public participation of all stakeholders is involved in the structure set-up. The promotion of public participation is at the core of the Constitution of the Republic of South Africa, 1996. Similarly, Chapter 2 of the Constitution of the Republic of South Africa, 1996, provides in the Bill of Rights that 'all citizens must be treated equally', which is a true reflection of the nation's democratic values regarding human dignity, equality and freedom, and the upholding of constitutional principles (Ijeoma 2013:419).

In summary, the above findings imply that the MuniMEC IGR arrangement can be the most appropriate and efficient means for enabling rapid, shared, and sustainable socioeconomic development at municipal level. The Eastern Cape Provincial IGR Summit (2017) agrees with these findings in that the only fundamental hope for the highly rural Eastern Cape Province is the strengthening of IGR structures, giving more legislative powers and resources to respond to socioeconomic development needs efficiently and effectively. Consequently, the establishment of the MuniMEC IGR structure in the province has greatly assisted the municipalities in delivering their constitutional mandate through collaborative efforts and structured coordination of service intervention programmes. According to Mnukwa (2019:5), Eastern Cape Province has most of its populace/population living in poverty. They experience inequality insofar as access to economic, political, and symbolic power is concerned. This situation highlights the fact that the Eastern Cape Provincial Government has a huge responsibility to intensify its development initiatives by promoting partnerships with the private sector in dealing with underdevelopment in the entire province. Based on the findings of the study, it can be said that the effectiveness and efficiency of the MuniMEC IGR arrangement in the coordination and integrations of government socio-economic development projects can only be improved by employing a shared IGR model. This is supported by the above findings from the MuniMEC participants with a mean of above $50 \%$. This means that the existence of the provincial MuniMEC structure has contributed greatly to job creation and poverty reduction. The above contentions endorse a positive narrative for the Eastern Cape Provincial government in the sense that the utilisation and strengthening of IGR structures would certainly contribute towards the realisation of the provincial

TABLE 5: Participation in the MuniMEC inter-government relations structure.

\begin{tabular}{lcccc}
\hline Frequency & E1 & E2 & E3 & Total average \\
\hline Never (1) & 2.94 & 14.7 & 5.9 & 7.84 \\
Rarely (2) & 8.82 & 20.6 & 23.5 & 17.64 \\
Sometimes (3) & 20.59 & 41.2 & 20.6 & 27.45 \\
Often (4) & 44.12 & 8.8 & 29.4 & 27.45 \\
Always (5) & 23.53 & 14.7 & 20.6 & 19.61 \\
\hline Total\% & $\mathbf{1 0 0}$ & $\mathbf{1 0 0}$ & $\mathbf{1 0 0}$ & $\mathbf{1 0 0 . 0 0}$ \\
\hline
\end{tabular}


priorities, which are aimed at improving the welfare of communities. This is in line with the findings from South African Law Reform Commission (2021:113).

Therefore, Provincial IGR strategy projects provide a framework that enables all spheres of government to work together with the view to improve public service delivery through the provision of infrastructure and related non-core services.

\section{Conclusion}

In conclusion, this study gave a perspective on IGR and MuniMEC IGR structure in the Eastern Cape, along with the challenges faced by this province and the service delivery programmes that are in place to improve the living conditions of communities. The Eastern Cape government has had more than a decade to devise systems and processes in a bid to respond to the inherited as well as newly emerging service delivery challenges. Institutional arrangements, systems and mechanisms have been implemented at executive, administrative and legislative levels. The transition to democracy in South Africa, after apartheid, led to serious fundamental changes in the formation and functioning of the State. This change led to the redefining of the responsibilities of the different spheres of government after the restriction of the IGR.

After more than two decades of democratic rule, the question about the functionality of new IGR frameworks, structures and procedures still surfaces in many intergovernmental platforms because of the issues of service delivery backlog that still prevails in the country. According to Reddy (2001), the most effective and efficient IGR approach is firstly to promote a culture of co-operation, trust and mutual respect. Secondly, it is to provide capacity building. One of the main constraints to effective service provision at the municipal level has been the lack of capacity. This reality, however, has been separated from the IGR discussions, which should be championed by the provincial level of government. According to RSA (1996), 'the national and provincial government have the legislative and executive authority to see to the effective performance by municipalities of their functions'.

There is a perception among some national departments that their provincial counterparts are not well prepared for intergovernmental meetings. The geographical isolation of some provinces makes speedy and effective interaction with national departments problematic (De Villiers 1999:6-10). This points to a gap that needs to be filled.

In summary, Freund (2014:9) writes that South Africa is during a very long-term era of slow growth and often stagnation while its economy is more dominated by high standard of living, limited public fiscal that continues to drop and high demand for service provision. The existence of the two IGR structures such as MuniMEC in the Eastern Cape Province has positively benefited the province in terms of social and economic development. However, more work still needs to be done to maximise benefits to the Eastern Cape communities.

\section{Recommendations}

Drawing from the above, it is critical for the Provincial Government, led by the coordinating departments (namely, the Office of the Premier (OTP), CoGTA and Provincial Treasury (PT) to consider expanding the IGR arrangements to the private sector through Public-Private Partnerships (PPPs) and Municipal Private Partnerships (MPPs) in order to better deal with the current socio-economic challenges faced by the province. The IGR arrangement model is both a unique political and socio-economic experiment which requires serious attention in assisting the South African municipalities in enhancing service delivery, good governance, rural and economic development towards sustainable economic growth.

\section{Acknowledgements}

The author Zolani Tafeni acknowledges and appreciates the assistance from the staff of the Department of Cooperative Governance \& Traditional Affairs (CoGTA) and Municipalities.

\section{Competing interests}

The authors have declared that no competing interest exists.

\section{Authors' contributions}

Both the authors contributed equally to this work.

\section{Ethical considerations}

This article followed all ethical standards for research without direct contact with human or animal subjects.

\section{Funding information}

This research received no specific grant from any funding agency in the public, commercial or not-for-profit sectors.

\section{Data availability}

The data that support the findings of this study are available from the Z.T., upon reasonable request. Data sharing is not applicable to this article.

\section{Disclaimer}

The views and opinions expressed in this article are those of the authors and do not necessarily reflect the official policy or position of any affiliated agency of the authors.

\section{References}

Antwi, S.K. \& Hamza, K, 2015, 'Qualitative and quantitative research paradigms in business research: A philocophicl reflection', Euaropean Jiournal of Busines and Management $7(3), 217-225$.

Babbie, E., 2015, The practice of social research. MindTap course list, 14th edn., Oxford University Press, Cape Town. 
Bryman, A., 2004, Social research methods, 2nd edn., Oxford University Press, Oxford. Bryman, A., 2016, Social research methods, 5th edn., Oxford University Press, Oxford. Budget Speech, 2014, Minister of Finance Pravic Gordan, viewed n.d., from https:// www.treasury.gov.za.

De Villiers, B., 1999, National-provincial co-operation - the potential role of provincia interest offices: the German experience, SAPR/PL, viewed n.d., from https://www. nomos-elibrary.de/10.5771/0506-7286-2002-2-232.pdf?download_full_pdf.

Dunne, M., Pryor, I. \& Yates, P., 2012, Becoming a researcher, Open University Press, Berkshire.

Eastern Cape Socio-Economic Consultative Council, 2015, Quarterly socio-economic development review, Gem Print, East London.

Freund, B., 2014, An assessment of the economic development of the Eastern Cape Metros since 1994 and their prospects, Ecsecc, East London.

Ijeoma, E., 2013, South Africa's public administration in context, Verity Publishers, Republic of South Africa, Pretoria.

Intergovernmental Relations Framework Act, 2005, Government Printers, Pretoria.

Lemon, A., O'Meara \& Winchester, B., 2004, Microsoft Encarta Encyclopaedia, Microsoft Corporation, New York.

Levy, N. \& Tapscott, C., 2001, 'Intergovernmental relations in South Africa: The challenges of co-operative government', in N. Levy \& C. Tapscott (eds.) Intergovernmental relations in South Africa. The challenges of co-operative government, pp. 1-21, IDASA, Cape Town.

Lucey, T., 2002, Quantitative Techniques, Cengage Learning EMEA, Boston, England.

Masaulle, P., 2017, State of the province address, Bisho, viewed n.d., from https:// www.gov.za/speeches/sopa-premier-phumulo-masualle-17-feb-2017e.

Masiya, T., Davids, Y.D. \& Mangai, M.S., 2019, Assessing service delivery: Public perception of municipal service delivery in South Africa, Administratio Publica.

Mditshwa, S., 2012, A Socio-economic impact analysis of selected national development agency funded projects in the eastern cape province, Nelson Mandela Metropolitan University, Port Elizabeth.
Mdliva, M., 2012, 'Co-operative governance and intergovernmental relations in South Africa: A case study of the Eastern Cape, KZN', Masters thesis, viewed n.d., from https://ukzn-dspace.ukzn.ac.za.

Mnukwa, M.L., 2019, Rural household dietary diversity and food security in Raymond Mhlaba local municipality.

Molebeleli, L.B., 2018, 'A cooperative government approach to domestic violence: The case of SAPS, Ikageng and the North West Department of Justice and Constitutional Development', Doctoral dissertation, North-West University.

National Development Plan, 2030, Our future make it work, viewed n.d., from https:// www.gov.za/sites.

National Development Plan, 2012, 2030 Our future make it work, viewed n.d., from https://www.gov.za/sites.

Reddy, P.S., 2001, 'Intergovernmental relations in South Africa', Politeia 20(1), 21-39.

Republic of South Africa, 1996, Constitution of the Republic of South Africa Act, 1996 Government Printers, Pretoria.

Republic of South Africa, 1998, White paper on local government service partnerships, section 2, Government Printers, Pretoria.

RSA/PRC, 1998, Presidential review commission: Developing a culture of good governance, Report of the Presidential Review Commission on the Reform and Transformation of the Public Service in South Africa, viewed 15 May 2020, from http://www.polity.org.za/govdocs/reports/presreview/index.html2010/02/29.

State of the Nation Address, 2010, President of the RSA, viewed n.d., from https:// www.gov.za.

Stats SA, 2019, Sustainable development goals: Country report 2019, viewed 06 November 2021, from http://www.statssa.gov.za/MDG/SDGs_Country_ Report_2019_South_Africa.pdf.

Tafeni, Z. \& Mngomezulu, B.R., 2020, 'A perspective on the budgetary impact of COVID-19 in government departments with specific reference to the Department of Cooperative Governance \& Traditional Affairs, Eastern Cape Province, South of Cooperative Governance \& Traditional Affairs, Eastern
Africa', Journal of Public Administration 55(4), 599-607.

The South African Law Reform Commission, 2021, Review of mechanisms of intergovernmental relations applicable to the social development sector, Published by the commission in its research series, Republic of South Africa, Pretoria. 